\title{
Den vanskelige tilgivelsen
}

\author{
Av Elisabeth Schanche, \\ forsteamanuensis i psykologi, Universitetet i Bergen. E-post: Elisabeth.Schanche@uib.no
}

Hvordan kan forsoning bli mulig etter urett er begått? En kunstutstilling $i$ Bergen utforsker dette i tilknytning til brutale og dramatiske historiske hendelser. Kan disse verkene også si oss noe om temaet tilgivelse i vår egen hverdag?

Kunst gjør det mulig for oss å ta inn og forholde oss til sider av virkeligheten som kan være overveldende hvis de vises direkte. Gjennom det kunstneriske uttrykket blir det som er smertefullt og skremmende, utholdelig. På den måten kan vi bevege oss nærmere og føle. Kunst kan vekke empati, og gi tilgang til perspektiver vi ellers ikke ville tenkt over. Kunst kan også vise oss hva som er menneskelig mulig, og dermed fremme håp.

Våren 2021 ble utstillingen Living/Forgiving/Remembering vist i Kunsthall $3.14 \mathrm{i}$ Bergen. Denne ga oss som publikum muligheten til å dvele ved de tre temaene som utgjør tittelen på forestillingen. Jeg ble invitert til å reflektere omkring tilgivelse - og er blitt oppfordet til å dele mine refleksjoner i Prismet.

Verkene på utstillingen baserer seg på tolv kunstneres representasjoner av hva krig og konflikter kan føre til i form av vold, dominans, dehumanisering, høye murer, og en konstant beredskap på at noe grusomt kan skje. Kunstnerne har tatt utgangspunkt i situasjoner fra Vietnamkrigen, Rwanda, Israel-Palestina, tidligere Jugoslavia, Sør-Afrika og Chile. De er samtidig opptatt av spørsmålet om tilgivelse er mulig. Kan en leve videre og bli gjenforent etter å ha opplevd urett og grusomhet?

I møte med verkene følte jeg meg ydmyk. Hvilken evne og ikke minst rett har jeg til å snakke om temaet tilgivelse, som hvit, privilegert og uten egen erfaring fra krig eller konflikter på det nivået som denne utstillingen viser?

Samtidig er det å håndtere overtredelser og emosjonelle skader relevant for oss alle. Selv om det er forskjeller i både type av erfaringer, intensitet, kultur og hudfarge, er det ikke noe «oss» og «dem». Vi har alle potensialet til å lukke oss, til å hate, til å dehumanisere den andre, og til å søke hevn. Og på den andre siden har vi potensialet til å tilgi.

Jeg er sikker på at jeg ikke er den eneste som vet hvor lett det er å stenge av for varme følelser når jeg opplever at noen har tråkket over grensene mine eller behandlet meg dårlig. Det kan skje selv i situasjoner som er på en mye mindre skala enn hendelsene representert i denne utstillingen. Tilgivelse kan virke som en god ide - helt til vi virkelig har noe å tilgi. Da kan det virke nærmest umulig. 


\section{HVa Vil tilgivelse Si?}

Tilgivelse kan forklares som en individuell, frivillig og indre prosess hvor vi gir slipp på følelser og tanker som kretser omkring harme, bitterhet, hat og hevn overfor noen som har såret eller skadet oss (Meneses \& Greenberg, 2019). Vi tilgir for å frigjøre oss selv fra disse intense følelsene og tankene. Tilgivelse er en organisk prosess. Å tilgi er ikke noe vi bare kan bestemme oss for. Ofte er det en smerte knyttet til det som har skjedd, som vi ikke bare kan skyve vekk. Det vi derimot kan, er å være villig til å ta del i en prosess som innebærer å vende oss mot og være til stede med vår egen smerte og våre egne sår på en måte som er til hjelp og kan lege. Ved å akseptere egne reaksjoner på det som har skjedd og møte dem med en varme og forståelse, kan vi bearbeide og bli mindre fanget av disse reaksjonene. Dette kan ta tid.

Ett av verkene som gjorde sterkt inntrykk på meg, var en billedserie fra Rwanda av fotografen Lana Mesic. For de som ønsker kan bildene sees her: https://www. lanamesic.com/work. Over tyve år etter folkemordet ble overgripere og ofre som del av et forsoningsarbeid invitert til å stille seg foran kamera og illustrere hvor de var i sin egen tilgivelsesprosess. Hutuer som hadde tatt inn over seg ugjerningene de hadde begått, ba sine ofre om tilgivelse. På bildene møter de familien til mennesker de hadde drept. Noen av gjerningsmennene kneler, noen står, andre igjen strekker fram hendene, noen ofre og gjerningsmenn holder rundt hverandre. Ofrene viser sine behov for fortsatte grenser gjennom kroppsspråk og nedslåtte blikk. Noen viser at de har mer behov for avstand enn andre. Det slo meg hvor avgjørende det er å respektere disse grensene, og hvor retraumatiserende det ville vært om noen insisterte på at de skulle gå nærmere for å iscenesette konvensjonelle forestillinger om tilgivelse og forsoning. Det å tilgi er en prosess hver enkelt må gjennomgå på sin måte og i sitt eget tempo.

\section{Trygghet Før TILgivelse}

Det er også viktig å respektere at det finnes en fase hvor det er for tidlig å tilgi. Først må vi være trygge for fare. Når noe sårer, skader eller truer oss fysisk og emosjonelt, må vi beskytte oss selv. Et godt bilde på dette er sjøanemoner. Når du berører dem, vil de sanse fare og trekke seg sammen. Vi har same type beredskap. Når vi føler oss truet, manipulert eller misbrukt trekker vi oss sammen i kroppen og i sinnet. Det er intelligens i denne sammentrekningen. Når vi er i pågående fare, er det ikke tiden for å føle empati for andre, eller analysere hva som foregår. Da er det tid for å beskytte oss selv og overleve, fysisk og emosjonelt.

Avhengig av situasjonen kan den beste måten å beskytte oss selv være å slåss. Å bruke sinnet vårt til å beskytte grensene våre og protestere mot pågående urett. Det kan også være å flykte, å komme seg ut av situasjonen hvis det er mulig. Hvis ikke kan det være å lukke seg, og gå inn i en tilstand hvor vi fryser til og gjør vårt 
beste for å være usynlige og unngå ytterligere fare. Det er i vårt alles nervesystem å reagere på disse ulike måtene.

Grenseoverskridelser og skader skaper emosjonelle sår og kanskje fysiske sår. Når det som skjer, er på en skala som er overveldende og umulig å bearbeide, har vi evnen til å isolere minnene og emosjonene som er knyttet til det som skjedde på innsiden, å skyve det ut av bevisstheten.

\section{Å IVARETA EGNE SÅR}

Når vi ikke lenger er i fare for å bli ytterligere skadet, er det første steget $\mathrm{i}$ prosessen å tilgi det å vende oss mot våre egne smertefulle følelser og reaksjoner. Dette innebærer å forholde seg til realiteten i vår egen lidelse. Ikke å benekte eller fortrenge vårt eget sinne, frykt, skam, smerte eller sorg, men bli bevisst på den, akseptere at den er der, og gjøre det vi klarer for å møte disse følelsene på en varm og omsorgsfull måte.

Det å være til stede med vår egen smerte, frykt og aktivering krever et enormt mot. Vi giør naturlig nesten alt for å unngå sårbarheten i oss selv.

Denne prosessen kan ta tid og giøre vondt. Særlig hvis det vi har erfart er overveldende og traumatisk. Symbolsk kan vi tenke på denne prosessen som en overgang fra å ha åpne sår til å ha arr.

Gjennom å stelle de emosjonelle sårene våre, kan vi gradvis bli mindre fanget av fortiden og reaksjonene våre på den. I denne prosessen kan vi trenge hjelp av støttespillerne våre, og noen ganger av sjelesorg eller terapi. Vi kan få større frihet til å velge hvordan vi forholder oss til minner fra fortiden, til følelsene disse minnene vekker, og til andre mennesker.

Det å være mindre fanget av hat, anklager og hevn, kan også giøre andre sider av oss selv mer tilgjengelige: Nysgjerrighet, evnen til å føle glede, interesse og tilhørighet. Ved å gi gradvis slipp på hat og anklager, kan en igjen få kontakt med egne ressurser og bredden i hvem en er. Det å være koplet på hele spekteret av følelser og ulike sider av oss selv bringer også ofte med seg en følelse av mening og hensikt.

Når sår gror og vi igjen kan bevege oss rundt $\mathrm{i}$ verden med mindre beskyttelse, kan vi oppleve en dypere kontakt med andre. I krig og konflikter blir de menneskelige nyansene i den andre ofte utilgjengelige for oss. Det å tilgi kan gjøre det mulig for oss å igjen se nyanser i den andre, og gjenoppdage deres menneskelighet.

\section{Misforstått Tilgivelse}

Samtidig er det også her tilgivelsesprosessen kan bli problematisk. Tilgivelse kan være vanskelig fordi vi ofte misforstår hva det innebærer. Vi frykter at det å tilgi betyr at vi skal benekte eller unnskylde den andres ansvar for å ha såret oss. At det minimerer eller rettferdiggjør uretten som er begått, eller gir signaler om at det er greit å utsette oss for ny urett. 
Moden tilgivelse betyr ikke at vi setter til side grensene våre. Det er mulig å tilgi, men velge å ikke ha personen som skadet oss, i livet lenger. Det vi gir slipp på når vi tilgir, er besettelsen på hevn og behovet for at de som skadet oss, skal lide og føle smerte. Det vi gir slipp på, er vårt eget hat - ikke erkjennelsen av at en urett er begått.

Det å leve med arr kan gjøre oss kloke. Vi har erfart ting som kan hjelpe oss å skille mellom hva som er bra og hva som kan skade. Vi kan bli mer klar over hva vi trenger, og hva vi ikke trenger. Vi kan bli mer lydhøre for signaler som informerer oss om grenser. Vi kan utvikle kapasiteten til å manøvrere på kloke måter.

Poenget er at det er en fare ved å fokusere på et bestemt endepunkt i tilgivelsesprosessen, som forsoning eller gjenopprettelsen av en forbindelse. Faren er at det kan føre til at vi forbigår de vonde følelsene vi trenger å bearbeide for at tilgivelse skal være helende og reelt transformerende.

Her vil jeg trekke fram verket «Gates of Paradise» av kunstneren Saad Qureshi fra utstillingen.

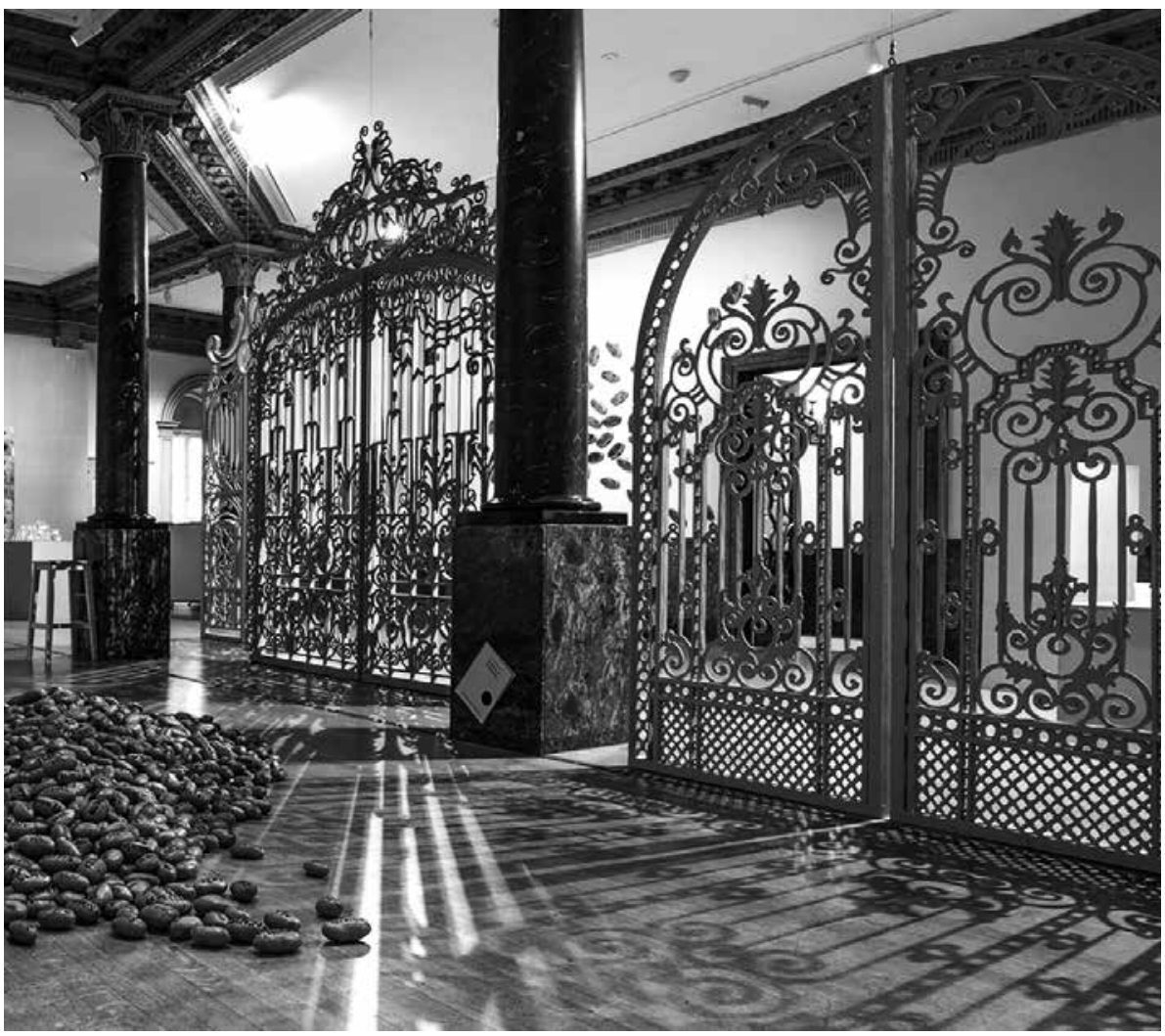

Foto: Kunsthall 3,14. 
Mønstrene på portene representerer en abstrahert fremstilling av sentrale symboler hentet fra ulike religioner og kulturer. Qureshi har til hensikt å fremheve likheter mellom ulike religioner og verdensbilder. Tilgivelse er ett område de fleste religioner og visdomstradisjoner fremhever som en høyere verdi eller prinsipp. De vakre portene kan åpnes og lukkes. Symbolsk kan de åpne opp for kontakt med noe større - men de kan også lukke igjen og begrense. For meg ble de en interessant metafor for den mulige dobbeltheten ved å forholde seg til religiøse prinsipper, som tilgivelse. Ut fra egne erfaringer med oppvekst $i$ et evangelisk kristent miljø, fungerte dette verket for meg som en illustrasjon på faren ved å skulle tilgi før en har fått lov til å kjenne på egne følelser og reaksjoner. Hvis vi føler vi må tilgi fordi det er forventet eller for å leve opp til et høyere ideal eller religiøst prinsipp, kan det føre til at en forbigår egne vanskelige følelser, og at disse dermed ikke blir bearbeidet. Det kan bidra til å fremmedgjøre oss fra egne følelser og evnen til å la oss informere av de erfaringene vi har og manøvrere på kloke måter. Vi kan da ende opp med å begrense og stenge av for sider av oss selv og fra en opplevelse av ekte tilhørighet fremfor å åpne opp for en større kontakt med helheten $i$ oss selv og den sammenheng vi inngår $i$.

\section{SUNN IKKE-TILGIVELSE?}

I historiene fra Rwanda går det fram at overgriperne innrømmer hva de har gjort, og aktivt ber om tilgivelse. De har vært villige til å ta inn og føle smerten og skammen over handlingene sine. Det er ikke alltid tilfelle. Verken i kriger og større konflikter, eller i våre personlige liv.

Terapeutisk arbeid med ofre har vist at i tilfeller hvor overgriper ikke innrømmer at de har gjort noe galt eller ber om tilgivelse, er det mulig for ofrene å velge å ikke tilgi den andre, men samtidig ikke lenger være besatt av følelser av hat og fantasier om hevn (Meneses \& Greenberg, 2019). Det er også mulig å være rasende over - men ikke oppslukt av - de skadene andre har påført en. Det er til og med mulig å ha sympati med og opprettholde kontakten med mennesker du nekter å tilgi. Kanskje trenger vi også begrepet sunn ikke-tilgivelse? Noen ganger tror jeg også vi trenger å tilgi oss selv for ikke å være klar for å gi slipp og gå videre. Det kan være gode grunner for at det å møte vanskelige følelser eller gi slipp på beskyttelse kan kreve ekstra tid for noen av oss. Kanskje har vi tidligere opplevd noe som giør oss ekstra sårbar for å bli sviktet eller dårlig behandlet? Kanskje har uretten som er begått, rippet opp i gamle sår? Ofte er det lettere å være empatisk og tålmodig med andre enn det er å møte seg selv på gode måter.

\section{Det Menneskelige potensiale}

Oppsummert er tilgivelse en prosess som kan ta tid. Det å sette i gang denne prosessen krever stort mot. Grunnen er at det å tilgi innebærer å forholde seg til 
vanskelige følelser og emosjonelle sår på en omsorgsfull måte. Det å tilgi er ikke noe vi bare kan bestemme oss for, men resultatet av en prosess som har vært tilstrekkelig legende til at det føles trygt å gi slipp på nok beskyttelse til at vi igjen kan åpne opp for helheten i livet og hvem vi er. Kunst kan gi oss et glimt av hvilket potensiale vi kan ha. Det å høre historier om og se bilder av personer som har gjennomgått det utenkelige og fremdeles ikke har gitt opp livet og dem rundt seg, gjør at jeg sitter igjen med en beundring og ærefrykt. Det mest menneskelige i oss kan være uant robust.

\section{LitTERATUR}

Meneses, C. W., \& Greenberg, L. S. (2019). Forgiveness and letting go in emotion-focused therapy. American Psychological Association. https://doi. org/10.1037/0000144-000 